\title{
Correction: Water intake after dehydration makes muscles more susceptible to cramp but electrolytes reverse that effect
}

Lau WY, Kato H, Nosaka K. Water intake after dehydration makes muscles more susceptible to cramp but electrolytes reverse that effect. BMJ Open Sport E Exercise Medicine 2019;5:e00478. doi: 10.1136/bmjsem-2018-000478

The authors want to alert readers to the following error identified in the published version.

Under the Experimental design section (paragraph 2, line 1), due to incorrect electrolyte value, the text has been updated as below:

OS-1 contains sodium (1150 mg/L), potassium (780 mg/L), magnesium (24 mg/L), chloride (1770 mg/L), glucose (18 $000 \mathrm{mg} / \mathrm{L})$ and others (eg, phosphorus).

Open access This is an open access article distributed in accordance with the Creative Commons Attribution Non Commercial (CC BY-NC 4.0) license, which permits others to distribute, remix, adapt, build upon this work non-commercially, and license their derivative works on different terms, provided the original work is properly cited, appropriate credit is given, any changes made indicated, and the use is non-commercial. See: http://creativecommons.org/licenses/by-nc/4.0/.

C Author(s) (or their employer(s)) 2019. Re-use permitted under CC BY-NC. No commercial re-use. See rights and permissions. Published by BMJ.

BMJ Open Sport Exerc Med 2019;5:000478corr1. doi:10.1136/bmjsem-2018-000478corr1

Check for updates 